\title{
Pengaruh Penerapan Model Pembelajaran Kooperatif Tipe Two Stay Two Stray (TSTS) terhadap Kemampuan Komunikasi Matematis Siswa Sekolah Menengah Pertama Telekomunikasi Ditinjau dari Kemampuan Awal.
}

\author{
Mukhammad Nurrokhim ${ }^{1}$, Depriwana Rahmi ${ }^{2}$, Depi Fitraini ${ }^{3}$ \\ 1,2,3Program studi pendidikan matematika, Universitas Islam Negeri Sultan Syarif Kasim Riau \\ e-mail: depriwanar@gmail.com
}

\begin{abstract}
ABSRTAK. Penelitian ini bertujuan untuk mengetahui perbedaan kemampuan komunikasi matematis antara siswa yang belajar menggunakan model pembelajaran kooperatif tipe Two Stay Two Stray (TSTS) dengan siswa yang belajar menggunakan pembelajaran konvensional jika ditinjau dari kemampuan awal pada siswa SMP Telekomunikasi. Penelitian ini merupakan penelitian Quasi Eksperimen dan desain yang digunakan adalah Nonequivalent Posttest-Only Control Group Design. Populasi penelitian ini adalah seluruh siswa kelas VIII SMP Telekomunikasi dan sampel dalam penelitian ini adalah siswa kelas VIII B dan kelas VIII C SMP Telekomunikasi yang diambil dengan menggunakan teknik purposive sampling. Teknik pengumpulan data yang digunakan adalah wawancara, observasi, dokumentasi dan tes. Instrumen yang digunakan dalam penelitian ini adalah pedoman wawancara, lembar observasi, dokumentasi, tes kemampuan awal, dan tes kemampuan komunikasi matematis. Teknik analisis data yang digunakan peneliti yaitu uji-t, dan anova dua arah (Two Way ANOVA). Berdasarkan hasil penelitian disimpulkan bahwa (1) Terdapat perbedaan kemampuan komunikasi matematis siswa antara siswa yang belajar menggunakan model pembelajaran Kooperatif Tipe TSTS dengan siswa menggunakan pembelajaran konvensional (2) Tidak terdapat perbedaan kemampuan awal siswa kelas eksperimen dan kelas kontrol (3) Tidak terdapat interaksi antara model pembelajaran Kooperatif Tipe TSTS dan kemampuan awal terhadap komunikasi matematis siswa. Dengan demikian secara umum model pembelajaran Kooperatif Tipe TSTS berpengaruh terhadap komunikasi matematis yang ditinjau dari kemampuan awal pada siswa SMP Telekomunikasi.

Kata kunci: Two Stay Two Stray (TSTS), Kemampuan Komunikasi Matematis, Kemampuan Awal, Quasi Eksperimen
\end{abstract}

\section{PENDAHULUAN}

Matematika merupakan alat yang tak terhingga nilainya untuk mengkomunikasikan berbagai ide dengan jelas, tepat dan ringkas. Karakteristik matematika yang abstrak, sarat dengan istilah dan simbol, mengakibatkan banyak yang hanya menelan mentah materi yang didapatkan tanpa mencoba untuk memahami informasi apa yang terkandung di dalamnya. Padahal, selama pembelajaran matematika hanya terfokus pada mengingat dan menghafal istilah-istilah, rumus, dan prosedur maka ide-ide yang terkandung dalam matematika tidak akan sampai (impenetrable).

Dalam lampiran Permendikbud Nomor 58 Tahun 2014 tentang Kurikulum SMP dijelaskan bahwa mata pelajaran matematika bertujuan agar siswa mendapatkan beberapa hal salah satunya yaitu mengomunikasikan gagasan, penalaran serta mampu menyusun bukti matematika dengan menggunakan kalimat lengkap, simbol, tabel, diagram, atau media lain untuk memperjelas keadaan atau masalah (Permendikbud, No. 58 Tahun 2014 tentang Standar Isi Kurikulum 2013 Untuk Satuan Pendidikan Dasar dan Menengah). Hal ini menujukan bahwa komunikasi matematis merupakan salah satu kemampuan penting yang harus dimiliki pada diri siswa.

Secara harfiah komunikasi berarti pemberitahuan, pembicaraan, percakapan, pertukaran pikiran, atau hubungan (Ngainun Naim, 2011). Komunikasi secara istilah dapat diartikan sebagai interaksi sosial melalui simbol dan sistem penyampaian pesan dari satu pihak kepada pihak lain 
agar terjadi pengertian bersama. Proses belajar mengajar hakikatnya adalah proses komunikasi, dimana guru berperan sebagai pengantar pesan dan siswa sebagai penerima pesan. Pesan yang dikirimkan oleh guru berupa isi atau materi pelajaran yang dituangkan ke dalam simbol-simbol komunikasi baik verbal (kata- kata dan tulisan) maupun nonverbal (Wina Sanjaya, 2008).

Meskipun kemampuan komunikasi matematis penting untuk dimiliki, tapi pada kenyataannya tidak demikian. Berdasarkan hasil penelitian pada tiga SMP Negeri di Pekanbaru, siswa masih banyak melakukan kesalahan terkait penyelesaian soal berbasis kemampuan komunikasi matematis. Secara garis besar, kesalahan-kesalahan tersebut yaitu: (1) siswa kurang mampu dalam menyatakan permasalahan dalam bentuk diagram; (2) siswa salah dalam menginterpretasi maksud soal; (3) Siswa kurang mampu dalam membaca diagram yang disajikan (Nufus dan Rezi: 2017)

Lebih lanjut, peneliti juga melakukan observasi, wawancara, dan uji tes untuk memperoleh data yang lebih akurat. Berdasarkan hasil observasi, wawancara dan hasil test yang telah peneliti lakukan dengan salah satu guru matematika SMP Telekomunikasi, didapat informasi bahwa kemampuan komunikasi matematis siswa SMP Telekomunikasi memang masih belum bisa dikatakan memuaskan. Hal ini dapat dikemukakan dalam beberapa gejala-gejala seperti sebagian besar siswa kesulitan menyelesaikan permasalahan matematika kedalam bentuk gambar atau grafik, kesulitan menyampaikan argument dan ide matematika yang dimilikinya, kesulitan meggunakan simbol-simbol matematika dalam menyelesaikan persoalan matematika, dan kesulitan mengambil kesimpulan dari pemecahan soal. Hal tersebut menunjukan bahwa kemampuan komunikasi matematis siswa masih tergolong rendah karena siswa masih kurang mampu memahami dan menerima gagasan/ide matematis sesuai dengan pengertian dari kemampuan komunikasi matematis, yaitu kemampuan menyampaikan gagasas/ide matematis, baik secara lisan maupun tulisan serta kemampuan memahami dan menerima gagasan/ide matematis orang lain secara cermat, anaitis, kritis, dan evaluatif untuk mempertajam pemahaman (Karunia Eka Lestari \& Mokhammad Ridwan Yudhanegara, 2017).

Berkaitan dengan masalah tersebut, maka peneliti menerapkan model pembelajaran yang dapat digunakan untuk memenuhi kebutuhan siswa dalam meningkatkan kemampuan komunikasi matematis. Peneliti memilih model pembelajaran kooperatif tipe Two Stay Two Stray (TSTS). Pembelajaran kooperatif tipe TSTS merupakan model pembelajaran yang memberikan kesempatan kepada kelompok untuk membagikan hasil dan informasi dengan kelompok lain. Pada tahap Two Stay (dua tinggal) dan Two Stray (dua bertamu) setiap anggota kelompok terlibat langsung, baik yang bertugas sebagai tamu untuk membandingkan jawaban dan berdiskusi dengan kelompok lain maupun yang bertugas sebagai penerima tamu untuk membagikan informasi kepada kelompok yang bertamu (Anita Lie, 2010). Pembelajaran kooperatif tipe TSTS siswa harus dapat menyampaikan pendapat dan menerima pendapat dari orang lain, sehinggga siswa dapat menghargai pendapat orang lain dan bertanggung jawab dengan tugasnya sehingga meningkatkan komunikasi matematis siswa dengan baik.

Model pembelajaran kooperatif tipe Two Stay Two Stray (TSTS) memiliki beberapa kelebihan. Menurut Aris Shoimin (2013) dalam buku Model Pembelajaran Inovatif dalam Kurikulum 2013 yaitu lebih berorientasi pada keaktifan siswa dan menambah kekompakan dan rasa percaya diri siswa. Adanya interaksi positif antar kelompok, maka akan melatih kemampuan siswa dalam berkomunikasi yang baik, dan memacu terbentuknya ide baru serta memperkaya perkembangan intelektual siswa.

Pada penelitian ini, indikator kemampuan komunikasi matematis yang digunakan yaitu: (1) Menulis (Written Text), siswa dapat menuliskan penjelasan dari jawaban permasalahannya secara matematis, masuk akal, dan jelas serta tersusun secara logis dan sistematis, (2) Menggambar (Drawing), siswa mampu melukiskan gambar, diagram atau tabel secara lengkap dan benar, (3) 
Ekspresi matematis (Mathematical Expressions), siswa mampu memodelkan matematika secara benar, kemudian melakukan perhitungan atau mendapatkan solusi secara lengkap dan benar.

Keterkaitan antara model kooperatif tipe TSTS dengan kemapuan komunikasi matematis adalah dalam model pembelajaran kooperatif tipe TSTS siswa dituntut untuk dapat berdiskusi dengan teman sekelompoknya dalam mengerjakan lembar kegiatan yang berkaitan dengan konsep materi. Kemudian siswa harus dapat mengkomunikasikan informasi berupa gagasan atau ide-ide matematika yang diperoleh dalam diskusi kelompok kepada teman kelompok lainnya. Sehingga siswa mampu untuk menyatakan konsep dan mengekspresikan solusi matematika secara tertulis, lisan maupun dalam bentuk visual lainnya. Dengan menerapkan model pembelajaran kooperatif TSTS, siswa akan lebih banyak melakukan kegiatan menyimak secara langsung, dalam artian tidak selalu dengan cara menyimak apa yang guru utarakan yang dapat membuat siswa jenuh. Dengan penerapan model pembelajaran TSTS, siswa juga akan terlibat secara aktif, sehingga akan memunculkan semangat siswa dalam belajar. Sedangkan tanya jawab dapat dilakukan oleh siswa dari kelompok satu dan oleh siswa dari kelompok satu dan yang lain, dengan cara mencocokan materi yang didapat dengan materi yang disampaikan. Jadi bisa di simpulkan pembelajaran kooperatif tipe TSTS bisa meningkatkan kemampuan komunikasi matematis siswa.

Faktor lain yang juga harus diperhatikan dalam pembelajaran adalah kemampuan awal. Melalui kemampuan awal siswa, dapat diketahui sejauh mana siswa telah mengetahui materi yang telah disajikan. Kemampuan awal siswa perlu diketahui karena merupakan salah satu faktor internal yang mempengaruhi prestasi belajar siswa karena kemampuan awal dapat menggambarkan kesiapan siswa dalam mengikuti suatu pelajaran.

Kemampuan awal matematika merupakan kemampuan yang dapat menjadi dasar untuk menerima pengetahuan baru. Kemampuan awal siswa adalah kemampuan yang telah dimiliki oleh siswa sebelum mengikuti kegiatan belajar mengajar. Siswa yang memiliki kemampuan awal setara bisa menjadi cemerlang atau terpuruk pada suatu mata pelajaran, bergantung pada kecintaan atau kebenciaannya pada pelajaran itu (Given Barbar, 2007). Kemampuan awal bertujuan untuk mengetahui tingkat pengetahuan dan keterampilan siswa sekarang agar guru mengetahui dari mana pengajaran harus dimulai. Sebagaimana yang dikutip oleh Mukhtar (2003) menyebutkan bahwa pengajaran berlangsung dari kemampuan awal sampai ke kemampuan terminal, itulah yang menjadi tanggung jawab pengajar. Kemampuan awal merupakan prasyarat yang harus dimiliki siswa untuk melanjutkan pembelajaran yang lebih tinggi.

Seseorang akan lebih mudah mempelajari sesuatu bila belajar itu didasari kepada apa yang telah diketahui orang itu. Karena itu untuk mempelajari suatu materi yang baru, pengalaman belajar yang lalu dari seseorang itu akan mempengaruhi terjadinya proses belajar materi matematika tersebut. Berdasarkan uraian tersebut jelas bahwa kemampuan awal sangat mempengaruhi proses pembelajaran matematika di dalam kelas. Oleh sebab itu setiap guru harus mengetahui kemampuan awal yang dimiliki masing-masing siswa untuk mempermudah terjadi proses pembelajaran yang baik.

Berdasarkan latar belakang di atas peneliti melakukan suatu penelitian dengan judul "Pengaruh Penerapan Model Pembelajaran Kooperatif Tipe Two Stay Two Stray (TSTS) terhadap Kemampuan Komunikasi Matematis Siswa Sekolah Menengah Pertama Telekomunikasi ditinjau dari Kemampuan Awal". Berdasarkan latar belakang masalah yang terurai, maka rumusan masalah dalam penelitian ini sebagai berikut:

1. Apakah terdapat perbedaan kemampuan komunikasi matematis siswa yang diajar dengan model pembelajaran tipe TSTS dengan siswa yang diajar dengan model pembelajaran konvensional?

2. Apakah terdapat perbedaan kemampuan awal siswa di kelas eksperimen dengan kemampuan awal siswa di kelas control? 
3. Apakah terdapat interaksi model pembelajaran tipe TSTS yang ditinjau dari kemampuan awal terhadap kemampuan komunikasi matematis siswa?

\section{METODE}

Penelitian ini dilaksanakan di kelas VIII SMP Telekomunikasi yang beralamat di Jl. Melati-Jl. Esemka No.5, Kec Tampan, pada semester genap tahun ajaran 2017/2018. Jenis penelitian yang dilaksanankan adalah Quasi eksperimen. Dimana, penelitian Quasi eksperimen ini merupakan suatu penelitian eksperimen semu, yang variabel-variabelnya tidak dikontrol sepenuhnya. Desain penelitian menggunakan Nonequivalent Posttestt Only Control Group Design (Karunia Eka Lestari \& Mokhammad Ridwan Yudhanegara, 2015). Berdasarkan desain ini terdapat dua kelompok yang dipilih secara langsung. Kelompok pertama diberi perlakuan (X) dan kelompok yang lain tidak. Kelompok yang diberi perlakuan disebut kelompok eksperimen dan kelompok yang tidak diberi perlakuan disebut kelompok kontrol. Didalam strategi ini sebelum dimulai perlakuan, kedua sampel diberikan test kemampuan awal untuk mengukur kondisi awal atau untuk mendapatkan data awal. Selanjutnya pada kelompok eksperimen diberikan perlakuan (X) dan kelompok kontrol tidak.

Populasi dalam penelitian ini adalah seluruh siswa kelas VIII SMP Telekomunikasi yang terdiri dari tiga kelas. Untuk Sampel dalam penelitian ini adalah kelas VIII SMP Telekomunikasi. Kelas VIII.C sebagai kelas eksperimen dan kelas VIII.B sebagai kelas kontrol dengan masingmasing jumlah siswa kelas VIII.C 24 orang dan siswa kelas VIII.B 23 orang. Kedua kelas tersebut telah diuji homogenitasnya. Pengambilan sampel dilakukan dengan teknik Purposive Sampling. Purposive Sampling yaitu teknik pengambilan sampel dengan memikirkan pertimbangan tertentu (Sugiyono, 2010:173). Sebelum sampel diberi perlakuan, maka perlu dianalisis terlebih dahulu melalui uji normalitas, uji homogenitas dan uji-t. Hal ini dilakukan untuk mengetahui apakah kedua sampel ini berasal dari kondisi awal yang sama. Data yang digunakan adalah data dari tes kemampuan awal.

Teknik pengumpulan data yang digunakan dalam penelitian ini adalah wawancara, observasi, teknik dokumentasi dan teknik tes. Wawancara yang dilakukan dalam penelitian ini yaitu untuk memperoleh informasi secara langsung dari guru mata pelajaran matematika dan mengetahui permasalahan yang sedang terjadi dalam pembelajaran matematika. Observasi dalam penelitian ini digunakan untuk mengamati aktivitas siswa dan aktivitas guru pada saat proses pembelajaran menggunakan model pembelajaran kooperatif tipe TSTS yang dilakukan setiap tatap muka. Observasi dilakukan dengan menggunakan lembar observasi, observasi dilakukan selama proses pembelajaran dengan menggunakan model pembelajaran kooperatif tipe TSTS, dimana yang diamati adalah aktifitas belajar siswa selama proses pembelajaran menggunakan model pembelajaran kooperatif tipe TSTS dan aktifitas mengajar pendidik pada tiap langkah pembelajaran terlaksana atau tidak sesuai dengan tindakan oleh pendidik. Peneliti secara langsung dapat mengambil bahan dokumen yang sudah ada dan memperoleh data yang dibutuhkan, seperti sejarah sekolah, keadaan guru dan siswa, sarana dan prasarana yang ada disekolah SMP Telekomunikasi. Tes yang digunakan dalam penelitian ini adalah dengan menggunakan tes kemampuan awal matematika (KAM) siswa dan posttest. Tes berbentuk uraian dan diberikan pada awal dan akhir penelitian. Tujuan dari tes ini adalah untuk menjawab hipotestis penelitian yang telah dirumuskan sebelumnya. Soal-soal test dirancang berdasarkan indikator kemampuan komunikasi matematis. Dari teknik pengumpulan maka instrumen yang digunakan dalam penelitian ini adalah wawancara, observasi, dokumentasi, tes kemampuan awal, dan tes kemampuan komunikasi matematis. Teknik analisis data yang digunakan adalah uji normalitas, uji homogenitas, dan uji hipotesis yang terdiri dari uji-t dan Uji ANOVA Dua Arah (Two Way ANOVA). 


\section{HASIL DAN PEMBAHAAN}

Penelitian berlangsung selama 4 kali pertemuan. Selama pelaksanaan penelitian aktivitas peneliti dan siswa dinilai oleh observer melalui lembar observasi yang telah dipersiapkan sebelumnya. Lembar observasi berisi uraian kegiatan inti yang harus dilaksanakan peneliti dan siswa selama proses pembelajaran berlangsung. Setiap pertemuan hasil observasi direkap dan observasi dihentikan ketika pelaksanaan kegitan pembelajaran TSTS terlaksana dengan baik dan sempurna. Rekap dari penilaian observer untuk 4 kali pertemuan pada kelas eksperimen disajikan pada tabel 1 berikut:

Tabel 1. Hasil Observasi Aktivitas Peneliti

\begin{tabular}{|c|c|c|c|c|c|}
\hline \multirow{2}{*}{ No } & \multirow{2}{*}{ Jenis Aktivitas } & \multicolumn{4}{|c|}{ Pertemuan } \\
\hline & & $\mathbf{I}$ & II & III & IV \\
\hline 1. & $\begin{array}{l}\text { Guru menyampaikan informasi tentang materi pembelajaran } \\
\text { yang hendak dicapai secara umum. }\end{array}$ & 3 & 4 & 4 & 4 \\
\hline 2. & $\begin{array}{l}\text { Guru membagi siswa kedalam } 5 \text { kelompok, setiap kelompok } \\
\text { terdiri dari } 4 \text { orang dan diminta duduk dalam kelompok yang } \\
\text { telah ditentukan. }\end{array}$ & 3 & 4 & 4 & 4 \\
\hline 3. & $\begin{array}{l}\text { Guru membagikan LKS pada tiap kelompok dan memberikan } \\
\text { kesempatan kepada semua siswa untuk mengerjakan LKS } \\
\text { yang diberikan }\end{array}$ & 3 & 4 & 4 & 4 \\
\hline 4. & $\begin{array}{l}\text { Guru memberikan bimbingan pada tiap kelompok yang } \\
\text { mendapat kesulitan dalam mengerakan soal. }\end{array}$ & 3 & 3 & 4 & 4 \\
\hline 5. & $\begin{array}{l}\text { Guru menunjuk dua orang siswa pada tiap kelompok untuk } \\
\text { berkunjung ke kelompok lain untuk mengamati hasil kerja } \\
\text { kelompok yang dikunjunginya. }\end{array}$ & 4 & 4 & 4 & 4 \\
\hline 6. & $\begin{array}{l}\text { Guru memberi waktu berdiskusi kelompok gabungan (yang } \\
\text { menerima dan berkunjung). }\end{array}$ & 3 & 3 & 3 & 4 \\
\hline 7. & $\begin{array}{l}\text { Guru meminta siswa yang berkunjung kembali ke kelompok } \\
\text { semula untuk melaporkan hasil kunjungannya dan } \\
\text { mendiskusikan kembali dengan kelompok asal. }\end{array}$ & 3 & 4 & 4 & 4 \\
\hline 8. & $\begin{array}{l}\text { Guru menyuruh salah satu kelompok untuk } \\
\text { mempresentasikan hasil kerja kelompoknya ke depan kelas, } \\
\text { sedangkan kelompok lain menanggapi. }\end{array}$ & 4 & 4 & 4 & 4 \\
\hline 9. & $\begin{array}{l}\text { Guru membimbing siswa menyimpulkan hasil diskusi } \\
\text { kelompok yang diperesentasikan. }\end{array}$ & 3 & 4 & 4 & 4 \\
\hline 10. & Guru memberikan penghargaan setiap kelompok. & 3 & 3 & 3 & 4 \\
\hline & Total & 32 & 37 & 38 & 40 \\
\hline & Persentase & 80 & 92,5 & 95 & 100 \\
\hline & Rata-rata Aktivitas guru dikelas eksperimen & & & 91,86 & \\
\hline
\end{tabular}

Berdasarkan tabel 1 rata-rata aktivitas peneliti dalam melaksanakan pembelajaran dengan menggunakan model pembelajaran kooperatif tipe TSTS sebesar 91,86\%. Selanjutnya, adapun aktivitas siswa selama proses pembelajaran disajikan dalam tabel 2 berikut:

Tabel 2. Hasil Observasi Aktivitas Siswa

\begin{tabular}{|c|c|c|c|c|c|}
\hline \multirow{2}{*}{ No } & \multirow{2}{*}{ Jenis Aktivitas } & \multicolumn{4}{|c|}{ Pertemuan } \\
\hline & & I & II & III & IV \\
\hline 1. & $\begin{array}{l}\text { Siswa menerima informasi tentang materi pembelajaran yang telah } \\
\text { ditentukan. }\end{array}$ & 3 & 4 & 4 & 4 \\
\hline 2. & Siswa duduk dalam kelompok yang telah ditentukan. & 3 & 3 & 4 & 4 \\
\hline 3. & Siswa langsung mengerjakan LKS yang telah diberikan guru. & 3 & 4 & 4 & 4 \\
\hline 4. & Siswa mengatasi kesulitan dalam mengerjakan soal. & 3 & 3 & 3 & 4 \\
\hline 5. & $\begin{array}{l}\text { Siswa yang berkunjung ke kelompok yang lain mengamati hasil kerja } \\
\text { kelompok dengan baik. }\end{array}$ & 3 & 3 & 4 & 4 \\
\hline 6. & Siswa menggunakan waktu yang telah ditetapkan guru dengan baik. & 3 & 3 & 4 & 4 \\
\hline
\end{tabular}




\begin{tabular}{|c|c|c|c|c|c|}
\hline 7. & $\begin{array}{l}\text { Siswa yang berkunjung dan telah kembali ke kelompok asal } \\
\text { melaporkan hasil kunjungannya dan berdiskusi dengan teman-teman } \\
\text { sekelompok. }\end{array}$ & 3 & 3 & 3 & 4 \\
\hline 8. & $\begin{array}{l}\text { Siswa yang ditunjuk oleh guru mempresentasikan hasil kerja kelompok } \\
\text { di depan kelas dengan baik. }\end{array}$ & 3 & 3 & 4 & 4 \\
\hline 9. & $\begin{array}{l}\text { Siswa menyimpulkan hasil diskusi kelompok yang telah } \\
\text { dipresentasikan. }\end{array}$ & 3 & 3 & 4 & 4 \\
\hline 10. & Siswa mendapat penghargaan dari guru atas kerja kelompoknya. & 3 & 3 & 3 & 4 \\
\hline & Total & 30 & 32 & 37 & 40 \\
\hline & Persentase & 75 & 80 & 92,5 & 100 \\
\hline
\end{tabular}

Berdasarkan tabel 2 rata-rata aktivitas belajar siswa menggunakan model pembelajaran kooperatif tipe TSTS sebesar 86,88\%. Berdasarkan tabel 1 dan tabel 2 diperoleh rata-rata pelaksanaan model pembelajaran TSTS oleh peneliti di kelas eksperimen adalah 91,86\% dan ratarata aktivitas siswa dalam pembelajaran menggunakan model pembelajaran TSTS di kelas eksperimen adalah $86,88 \%$. Hal ini menunjukkan pelaksanaan pembelajaran menggunakan model pembelajaran kooperatif tipe TSTS terlaksana dengan baik dan memenuhi semua karakteristik pendekatan TSTS. Untuk selanjutnya diberikan soal posttest berupa soal uraian.

Dalam penelitian ini ada dua jenis tes yang dilakukan yaitu:

1. Tes kemampuan awal matematis (KAM) dibuat untuk mengukur kemampuan awal siswa di kelas eksperimen dan kelas konrol. Siswa diberi tes KAM dengan materi prasyarat yang akan dipelajari siswa. Pemilihan soal-soal berdasarkan pertimbangan bahwa soal itu telah memenuhi standar nasional sebagai alat ukur yang baik. Dalam penelitian ini, soal KAM yang diberikan sebanyak 5 buah.

2. Posttest kemampuan komunikasi matematis disusun dalam bentuk test uraian. Posttest kemampuan komunikasi matematis siswa yaitu tes yang diberikan setelah semua materi diajarkan kepada siswa, untuk mengukur kemampuan komunikasi matematis siswa pada kelas eksperimen dan kelas kontrol setelah diberi perlakuan. Dalam penelitian ini, soal posttest yang diberikan sebanyak 5 buah.

Sebelum soal KAM dan Posttest diberikan kepada sampel, soal tersebut diujicobakan untuk melihat beberapa kriteria soal yang baik untuk digunakan. Analisis yang dilakukan terhadap soal tes yang diujicoba adalah:

1. Validitas butir tes

Hasil uji validitas soal KAM dan Posttest dapat dilihat pada tabel 3 dan tabel 4 berikut:

Tabel 3. Hasil Pengujian Validitas Butir Soal Uji Coba KAM

\begin{tabular}{|ccccc|}
\hline $\begin{array}{c}\text { No Butir } \\
\text { Soal }\end{array}$ & $\begin{array}{c}\text { Koefisien Korelasi } \\
\text { rhitung }\end{array}$ & Harga thitung & Harga t tabel & Keputusan \\
\hline 1 & 0,82 & 6,876 & 1,714 & Valid \\
2 & 0,557 & 3,198 & 1,714 & Valid \\
3 & 0,49 & 2,695 & 1,714 & Valid \\
4 & 0,674 & 4,375 & 1,714 & Valid \\
5 & 0,673 & 4,362 & 1,714 & Valid \\
\hline
\end{tabular}

Tabel 4. Hasil Pengujian Validitas Butir Soal Uji Coba Posttest

\begin{tabular}{|ccccc|}
\hline $\begin{array}{c}\text { No Butir } \\
\text { Soal }\end{array}$ & $\begin{array}{c}\text { Koefisien Korelasi } \\
\mathbf{r}_{\text {hitung }}\end{array}$ & Harga thitung & Harga t tabel & Keputusan \\
\hline 1 & 0,63 & 3,899 & 1,714 & Valid \\
2 & 0,356 & 1,825 & 1,714 & Valid \\
3 & 0,606 & 3,651 & 1,714 & Valid \\
4 & 0,796 & 6,311 & 1,714 & Valid \\
5 & 0,669 & 4,319 & 1,714 & Valid \\
\hline
\end{tabular}


2. Reliabilitas tes

Berdasarkan hasil uji coba reliabilitas butir soal KAM secara keseluruhan diperoleh koefisien reliabilitas tes sebesar 0,639 yang berarti bahwa tes hasil mempunyai reliabilitas sedang. Sedangkan hasil soal kemampuan komunikasi matematis diperoleh reliabilitas butir soal adalah 0,581 yang berarti soal posttest juga mempunyai reliabilitas sedang.

3. Tingkat kesukaran soal

Hasil uji tingkat kesukaran soal KAM dan Posttest dapat dilihat pada tabel 5 dan tabel 6 berikut:

Tabel 5. Tingkat Kesukaran Soal KAM

\begin{tabular}{|ccc|}
\hline $\begin{array}{c}\text { No } \\
\text { Soal }\end{array}$ & Tingkat Kesukaran & Kriteria \\
\hline 1 & 0,6 & Sedang \\
2 & 0,61 & Sedang \\
3 & 0,307 & Sedang \\
4 & 0,547 & Sedang \\
5 & 0,36 & Sedang \\
\hline
\end{tabular}

Tabel 6. Tingkat Kesukaran Soal Posttest

\begin{tabular}{|ccc|}
\hline $\begin{array}{c}\text { No } \\
\text { Soal }\end{array}$ & Tingkat Kesukaran & Kriteria \\
\hline 1 & 0,66 & Sedang \\
2 & 0,72 & Mudah \\
3 & 0,36 & Sedang \\
4 & 0,29 & Sukar \\
5 & 0,31 & Sedang \\
\hline
\end{tabular}

4. Daya pembeda soal

Hasil uji daya pembeda soal KAM dan Posttest dapat dilihat pada tabel 7 dan tabel 8 berikut:

Tabel 7. Daya Pembeda Soal KAM

\begin{tabular}{|c|c|c|}
\hline No Soal & Daya Pembeda & Kriteria \\
\hline 1 & 0,64 & Baik \\
\hline 2 & 0,35 & Cukup \\
\hline 3 & 0,29 & Cukup \\
\hline 4 & 0,32 & Cukup \\
\hline 5 & 0,52 & Baik \\
\hline
\end{tabular}

Tabel 8. Daya Pembeda Soal Posttest

\begin{tabular}{|c|c|c|}
\hline No Soal & Daya Pembeda & Kriteria \\
\hline 1 & 0,44 & Baik \\
\hline 2 & 0,13 & Jelek \\
\hline 3 & 0,56 & Baik \\
\hline 4 & 0,59 & Baik \\
\hline 5 & 0,43 & Baik \\
\hline
\end{tabular}

Setelah soal posttest memenuhi kriteria dan layak digunakan maka soal tersebut digunakan untuk mengukur kemampuan komunikasi matematis siswa. Tes dilakukan di akhir pertemuan setelah pembelajaran TSTS terlaksana dengan baik. Data yang diperoleh adalah hasil belajar siswa dengan menerapkan model pembelajaran kooperatif tipe TSTS pada kelas eksperimen serta membandingkan kemampuan komunikasi matematis siswa tersebut dengan kelas kontrol yang menggunakan pembelajaran konvensional. Sesuai dengan data yang diperoleh, maka analisis data 
dilakukan dengan uji t. Namun penggunaan uji t tersebut harus memenuhi dua syarat yaitu uji Homogenitas dan Normalitas. Adapun hasil uji normalitas dapat dilihat pada tabel 9 berikut:

Tabel 9. Uji Normalitas

\begin{tabular}{|clll|}
\hline Kelas & $\boldsymbol{X}^{2}$ hitung & $\boldsymbol{X}^{2}$ tabel & Kriteria \\
\hline Eksperimen & 6,945 & 11,071 & Normal \\
Kontrol & 9,135 & 11,071 & Normal \\
\hline
\end{tabular}

Berdasarkan tabel 9, dapat diamati bahwa nilai $X^{2}$ bitung kelas eksperimen sebesar 6,945 sedangkan untuk nilai $X^{2}{ }_{\text {bitung }}$ kelas kontrol sebesar 9,135. Harga $X^{{ }_{\text {tabel }}}$ dalam taraf signifikansi 5\% adalah 11,071 untuk kelas eksperimen dan 11,071 untuk kelas kontrol. Jadi hasil uji normalitas data nilai hasil belajar matematika siswa adalah Normal. Sedangkan hasil uji homogenitas dapat diperoleh dari tabel 10 berikut:

Tabel 10. Uji Homogenitas

\begin{tabular}{|c|c|c|}
\hline \multirow{2}{*}{$\begin{array}{l}\text { Nilai Varians } \\
\text { Sampel }\end{array}$} & \multicolumn{2}{|c|}{$\begin{array}{c}\text { Perbedaan Kelas Eksperimen dan Kelas } \\
\text { Kontrol }\end{array}$} \\
\hline & Kelas Eksperimen & Kelas Kontrol \\
\hline $\mathrm{S}^{2}$ & 120,12 & 71,57 \\
\hline $\mathrm{N}$ & 24 & 23 \\
\hline
\end{tabular}

Dari tabel 10 diperoleh nilai $F_{\text {bitung }}$ dengan rumus sebagai berikut:

$$
F_{\text {hitung }}=\frac{\text { varians terbesar }}{\text { varians terkecil }}=\frac{120,12}{71,57}=1,678
$$

Setelah itu bandingkan nilai $F_{\text {hitung }}$ dengan $F_{\text {tabel }}$ dengan rumus $: d b_{\text {pembilang }}=n-1=$ $24-1=23$ (untuk varians terbesar) dan $d b_{\text {penyebut }}=n-1=23-1=22$ (untuk varians terkecil). Nilai taraf signifikan $(\alpha)=0,05$ maka diperoleh $F_{\text {tabel }}=2,038$. Dengan demikian, diketahui bahwa $F_{\text {hitung }} \leq F_{\text {tabel }}$ yaitu $1,678<2,038$ sehingga $\mathrm{H}_{0}$ diterima dan $\mathrm{H}_{\mathrm{a}}$ ditolak. Dapat disimpulkan bahwa varian-varian adalah homogen.

Sesuai dengan rumusan masalah penelitian, maka teknik yang digunakan dalam menganalisis data untuk menguji hipotesis 1 dan 2 adalah dengan menggunakan uji t jika datanya berdistribusi normal dan homogen. Tujuan dari uji ini adalah untuk mengetahui apakah kemampuan komunikasi matematis siswa kelas eksperimen lebih baik dari kemampuan komunikasi matematis kelas kontrol. Uji dilakukan dengan kriteria jika nilai signifikan yang diperoleh lebih kecil dari 0,05 maka $\mathrm{H}_{\mathrm{a}}$ diterima, jika nilai signifikan yang diperoleh lebih besar dari 0,05 maka $\mathrm{H}_{0}$ diterima. Sedangkan untuk menguji hipotesis 3 digunakan anova dua arah. Dari hasil analisis diperoleh hasil sebagai berikut:

1. Terdapat perbedaan kemampuan komunikasi matematis antara siswa yang mengikuti model pembelajaran kooperatif tipe TSTS dengan siswa yang mengikuti pembelajaran konvensional. Hal ini dapat dilihat dari nilai $t_{\text {hitung }} 2,44$ dan $t_{\text {tabel }} 2,014$ pada taraf signifikan $5 \%$. Sehingga nilai $t_{\text {hitung }}>t_{\text {tabel }}$ yang berarti $\mathrm{H}_{\mathrm{a}}$ diterima dan $\mathrm{H}_{0}$ ditolak.

2. Tidak terdapat perbedaan kemampuan awal siswa di kelas eksperimen dengan kemampuan awal siswa di kelas kontrol. Hal ini dapat dilihat dari $t_{\text {hitung }}<t_{\text {tabel }}$ yaitu $0,868<2.014$, pada taraf signifikan 5\%. Sehingga $H_{o}$ diterima dan $H_{a}$ ditolak.

3. Uji Two $W$ ay Anova 
Hasil uji two way anova dapat dilihat pada tabel 11 berikut ini:

Tabel 11. Uji Two Way Avova Tes Kemampuan Komunikasi Matematis

\begin{tabular}{|c|c|c|c|c|c|c|}
\hline $\begin{array}{l}\text { Sumber } \\
\text { Variansi }\end{array}$ & Dk & JK & RK & Fh & Fk & Kesimpulan \\
\hline $\begin{array}{l}\text { Antar baris } \\
\text { (Model) }\end{array}$ & 1 & 8223,61 & 4111,8 & 75,64 & 4,079 & $\begin{array}{l}\text { Terdapat pengaruh } \\
\text { faktor KAM terhadap } \\
\text { kemampuan } \\
\text { komunikasi matematis } \\
\text { Terdapat pengaruh } \\
\text { faktor model } \\
\text { pembelajaran terhadap } \\
\text { komunikasi matematis }\end{array}$ \\
\hline $\begin{array}{c}\text { Interaksi } \\
\mathrm{KAM}^{*} \\
\text { Model }\end{array}$ & 2 & 3,68 & 1,84 & 0.034 & 3,226 & $\begin{array}{l}\text { Tidak terdapat } \\
\text { pengaruh interaksi } \\
\text { antara model } \\
\text { pembelajaran dengan } \\
\text { KAM terhadap } \\
\text { komunikasi matematis }\end{array}$ \\
\hline $\mathrm{JK}_{\mathrm{t}}$ & 41 & & & & & \\
\hline
\end{tabular}

Berdasarkan tabel 11 dapat disimpulkan bahwa faktor model pembelajaran memberikan pengaruh yang signifikan terhadap kemampuan komunikasi matemtis. Hal ini terlihat dari nilai signifikan untuk model pembelajaran adalah 75,64. Faktor KAM belajar juga memberikan pengaruh yang signifikan terhadap kemampuan komunikasi matematis. Hal ini terlihat dari nilai signifikan untuk KAM adalah 3,217.

Untuk melihat ada atau tidaknya interaksi antara model pembelajaran dan kemampuan awal matematis siswa terhadap kemampuan komunikasi matematis, kriteria pengujian adalah jika signifikan $\mathrm{Fh}>\mathrm{Fk}$ maka hipotesis diterima.

Tabel 6 memperlihatkan nilai $\mathrm{Fh}$ yang diperoleh adalah 0,034 dengan Fk 3,226. Hal ini berarti hipotesis yang menyatakan $\mathrm{H}_{0}$ diterima, artinya tidak terdapat interaksi antara model pembelajaran dan KAM. Oleh karena itu, kemampuan komunikasi matematis siswa karena pengaruh strategi pembelajaran tidak bergantung pada peringkat KAM siswa dan kemampuan komunikasi matematis siswa karena pengaruh peringkat KAM tidak bergantung pada penggunaan strategi pembelajaran. Berdasarkan kesimpulan diatas analisis pasca anova tidak dilanjutkan pada interaksi

\section{KESIMPULAN}

Berdasarkan hasil penelitian, dapat diambil kesimpulan bahwa: 1) Terdapat perbedaan kemampuan komunikasi matematis antara siswa yang mengikuti model pembelajaran kooperatif tipe TSTS dengan siswa yang mengikuti pembelajaran konvensional. Hal ini dapat disimpulkan pemebelajaran kooperatif tipe TSTS lebih baik dari pada pembelajaran konvensional dengan melihat dari nilai $t_{\text {hitung }} 2,44$ dan $t_{\text {tabel }} 2,014$ pada taraf signifikan $5 \%$. maka nilai $t_{\text {hitung }}>$

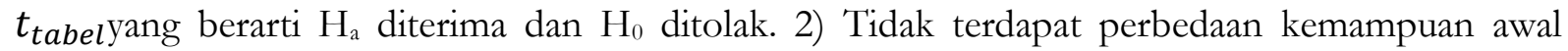
siswa di kelas eksperimen dengan kemampuan awal siswa di kelas kontrol. Hal ini dapat dilihat dari $t_{\text {hitung }}<t_{\text {tabel }}$ yaitu $0,868<2.014$, pada taraf signifikan $5 \%$. Sehingga $H_{o}$ diterima dan $H_{a}$ ditolak. 3) Tidak terdapat interaksi antara model pembelajaran kooperatif tipe TSTS ditinjau dari kemampuan awal siswa terhadap kemampuan komunikasi matematis Hal ini dapat dilihat dari nilai $F_{\text {hitung }}<F_{\text {tabel }}$ yaitu $0,034<3,226$ pada taraf signifikan 5\%. Sehingga $H_{o}$ diterima dan $H_{a}$ ditolak. 


\section{REFERENSI}

Barbar, G. (2007). Brain-Based Teaching, Terj. Lala Herawati Darma, Bandung: Kaifa.

Lestari, K. E. dan Yudhanegara, M. R. (2015). Penelitian Pendidikan Matematika. Bandung: PT. Refika Aditama

Mukhtar. (2003). Desain Pembelajaran Pendidikan Agama Islam. Jakarta: CV Misaka Galiza.

Naim, N. (2011). Dasar-Dasar Komunikasi Pendidikan. Jogjakarta: Ar-Ruzz Media.

Nufus, Hayatun dan Rezi Ariawan. (2017). Keterkaitan Hubungan antara Kemampuan Komunikasi dan Penalaran Matematis Siswa. Jurnal Symmetry: Pasundan Journal of Research in Mathematics Learning and Education, Vol. 1 No. 2, hal. 29 - 42.

Permendikbud. (2014). No. 58 Tentang Standar Isi Kurikulum 2013 Untuk Satuan Pendidikan Dasar dan Menengah

Sanjaya, W. (2006). Strategi Pembelajaran Berorientasi Standar Proses Pendidikan. Jakarta: Kencana Prenada Media Group.

Shoimin, A. (2014). 68 Model Pembelajaran Inovatif dalam Kurikulum 2013. Yogyakarta: Ar-Ruzz Media.

Sugiyono. (2013). Metode Penelitian Kuatitatif Kualitatif dan Re๗D. Bandung: Alfabeta. 